\title{
Avanços em testes genéticos pré-implantacionais: revisão de literatura
}

\author{
Advances in pre implantation genetic tests: literature review \\ Avances em pruebas genéticas pre implantacionales: revisión de la literatura
}

\section{Resumo}

O desenvolvimento das tecnologias genéticas pré-implantacionais nos permite, hoje, identificar anomalias genéticas hereditárias, realizar triagem em busca de mutações e analisar previamente a viabilidade de um embrião, inclusive conhecer a compatibilidade genética embrionária com a de uma pessoa já nascida e doente, que necessite de um doador compatível. Os testes genéticos pré-implantacionais consistem em um conjunto de técnicas, realizadas após o processo de Fertilização in vitro (FIV) e antes da implantação do embrião. Devido à escassez de artigos na literatura brasileira sobre o assunto, foi desenvolvida uma revisão de literatura, que tem como objetivo explanar sobre os avanços que ocorreram nos últimos 30 anos nos testes utilizados para o diagnóstico genético pré-implantacional (DGPI), esclarecendo e apresentando seus protocolos. Para isso, foram selecionadas as principais técnicas adotadas, sendo elas Nested PCR, Multiplex PCR, qPCR, FISH, aCGH, SNP's, NGS Ion Torrent e Illumina, além de contextualizar a cronologia dos testes e apresentar todo o contexto ético que os envolve. Para tanto, foram utilizadas 48 referências de língua inglesa, portuguesa e espanhola, em sua maioria datadas entre 2017 a 2021 . É fato que o DGPI confere um grande avanço no campo da reprodução assistida e possibilita mulheres com idade avançada ou histórico recorrente de aborto, além de pessoas com anomalias genéticas, terem o DNA de seus embriões analisados antes de sua implantação, permitindo identificar mutações que poderão afetar a saúde do bebê e garantindo a sua compatibilidade com a vida.

Palavras-chave: DGPI; Bioética; Fertilização in vitro; Reprodução Assistida.

\begin{abstract}
The development of pre-implantation genetic technologies allows us to identify hereditary genetic anomalies, perform screening for mutations and, previously analyze the viability of an embryo, including knowing the embryonic genetic compatibility with that of a person already born and sick, who need a compatible donor. Preimplantation genetic tests consist of a set of techniques, performed after the in vitro fertilization (IVF) process and before embryo implantation. Due to the scarcity of articles in the Brazilian literature on the subject, a literature review was developed, which aims to explain the advances that have taken place in the last 30 years in tests used for preimplantation genetic diagnosis (PGD), clarifying and presenting their protocols. For this, the main adopted techniques were selected, namely Nested PCR, Multiplex PCR, qPCR, FISH, aCGH, SNP's, NGS Ion Torrent, and Illumina, in addition to contextualizing the chronology of the tests and presenting the entire ethical context that involves them. For this purpose, 48 references were used in English, Portuguese, and Spanish, mostly dating from 2017 to 2021. It is a fact that the DGPI provides a great advance in the field of assisted reproduction and allows women of advanced age or recurrent history of abortion, in addition to people with genetic abnormalities, to have the DNA of their embryos analyzed before its implantation, allowing the identification of mutations that could affect the baby's health and guaranteeing its compatibility with life. Keywords: DGPI; Bioethics; In vitro fertilization; Assisted Reproduction.
\end{abstract}




\begin{abstract}
Resumen
El desarrollo de tecnologías genéticas preimplantacionales nos permite identificar anomalías genéticas hereditarias, realizar cribado de mutaciones y analizar previamente la viabilidad de un embrión, incluyendo conocer la compatibilidad genética embrionaria con la de una persona ya nacida y enferma, que necesita un donante compatible. Las pruebas genéticas preimplantacionales consisten en un conjunto de técnicas, realizadas después del proceso de fertilización in vitro (FIV) y antes de la implantación del embrión. Debido a la escasez de artículos en la literatura brasileña sobre el tema, se desarrolló una revisión de la literatura, que tiene como objetivo explicar los avances que se han producido en los últimos 30 años en las pruebas utilizadas para el diagnóstico genético preimplantacional (DGP), aclarando y presentando sus protocolos. Para ello, se seleccionaron las principales técnicas adoptadas, a saber, PCR anidada, PCR multiplex, qPCR, FISH, aCGH, SNP's, NGS Ion Torrent e Illumina, además de contextualizar la cronología de las pruebas y presentar todo el contexto ético que las involucra. Para ello se utilizaron 48 referencias en inglés, portugués y español, en su mayoría datadas de 2017 a 2021. Es un hecho que la DGPI aporta un gran avance en el campo de la reproducción asistida y permite a mujeres en edad avanzada o antecedentes recurrentes de aborto, además de personas con anomalías genéticas, tener analizado el ADN de sus embriones antes de su implantación, permitiendo la identificación de mutaciones que pudieran afectar la salud del bebé y garantizando su compatibilidad con la vida.
\end{abstract}

Palabras clave: DGPI; Bioética; Fertilización in vitro; Reproducción asistida.

\title{
1. Introdução
}

O desenvolvimento das tecnologias genéticas pré-implantacionais após a realização das técnicas de fertilização in vitro nos permitem, hoje, identificar anomalias genéticas hereditárias, realizar triagem genética em busca de mutações e analisar previamente a viabilidade de um embrião, inclusive conhecer a compatibilidade genética deste com a de uma pessoa já nascida e doente, que necessite de um doador compatível. Este fato só é possível através de técnicas de análise do DNA (PGTpre implantation genetic testing e PGS- pre implantation genetic screening), na qual se faz o diagnóstico genético préimplantacional (DGPI) (Harton et al., 2010).

A prática de DGPI, ainda cercada de dilemas éticos, tem possibilitado mulheres com idade avançada ou histórico recorrente de aborto e pessoas com mutações já conhecidas (além de pessoas que não sabem que carregam certas mutações) terem o material genético de seus embriões analisados, antes da transferência embrionária, permitindo a identificação de mutações que poderão afetar a saúde do bebê e garantindo a sua compatibilidade com a vida (Sullivan-Pike \& Dokras, 2018; Guerra \& Catdin, 2019).

Os avanços nas técnicas de cultivo de embriões permitiram o aprimoramento das técnicas de biópsia das células embrionárias, possibilitando coletar um número maior de células sem prejudicar o desenvolvimento do embrião. Da coleta de células dos $1^{\circ}$ e $2^{\circ}$ corpúsculos polares, onde só era possível analisar o material genético da mãe, avançou-se para a biópsia do blastômero e biópsia do trofoblasto, que permitem análise concomitante do material genético do pai e da mãe, além da coleta de maior quantidade de material genético (Sullivan- Pyke \& Dokras, 2018).

Tendo em vista a extrema importância do DGPI para o avanço da Reprodução Assistida, este estudo visa apresentar as técnicas atualmente utilizadas no mundo, com ênfase no Brasil, para rastrear qualquer alteração ou distúrbio genético, previamente à implantação de embriões concebidos pelo processo de fertilização in vitro (FIV), através do DGPI (Gonçalves et al., 2019). Os avanços nas técnicas de análise cromossomal e genética, que incluem o PCR (polymerase chain reaction), hibridização in situ por fluorescência (FISH), sequenciamento de próxima geração (NGS), técnicas de microarray como polimorfismo de único nucleotídeo (SNP) e hibridização genômica comparativa por array (aCGH) foram fundamentais para o DGPI e serão o foco da presente revisão.

\section{Metodologia}

Essa pesquisa constitui-se de uma revisão integrativa de literatura, tendo como abordagem o método qualitativo, caracterizado pela combinação de diferentes estudos, disposto a gerar compreensão sobre o assunto escolhido (Pereira et al., 
2018, Proetti, 2018), avanços em testes genéticos utilizados para diagnóstico patológico durante a fase pré-implantacional embrionária. Para a elaboração desta revisão, foi feito um levantamento na literatura nacional e internacional, utilizando os bancos de dados Pubmed, Scielo, Biblioteca Virtual em Saúde (BVS Brasil), Google Acadêmico e Sciensce Pub. Os descritores utilizados para a pesquisa foram: "diagnóstico genético pré-implantacional", "testes genéticos", "PGD”, "bioética", "PGS”, "FISH", "PCR", “aCGH", "SNP” e "NGS".

Os critérios de inclusão para esta pesquisa foram o acesso completo aos artigos com temática referente aos testes genéticos utilizados para diagnóstico patológico durante a fase pré-implantacional, publicados, na sua maioria, entre 20172021. No total, foram selecionados 50 artigos utilizando os descritores para fundamentar esta pesquisa.

Os critérios de exclusão foram desvio ao tema da pesquisa e acesso incompleto ao artigo (Figura 1).

Figura 1: Fluxograma da seleção dos estudos utilizados para essa pesquisa.

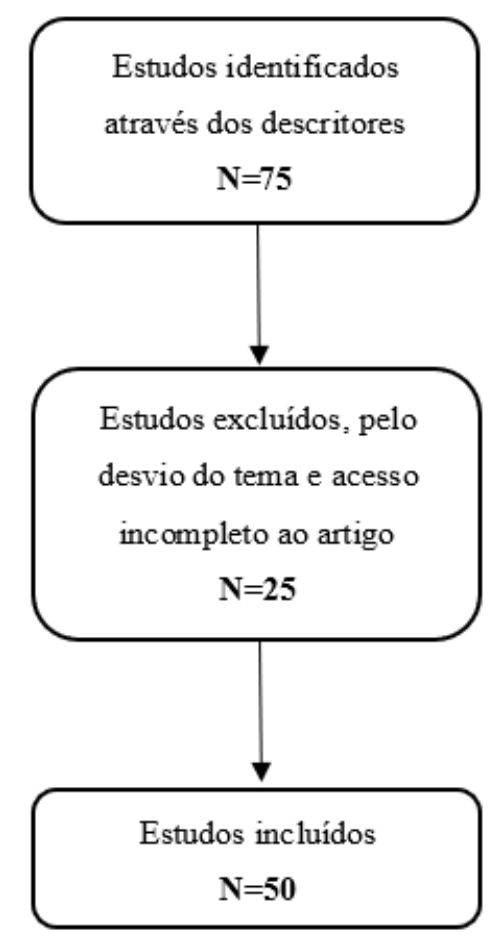

fonte: Autores.

\section{Resultados e Discussão}

\subsection{Histórico dos testes pré-implantacionais}

Os precursores do diagnóstico genético pré-implantacional (DGPI) foram Gardner e Edwards, em 1967, que realizaram a biopsia de um blastocisto de coelho. Após a biópsia, sucedeu a análise da X-cromatina, e eles observaram a aplicabilidade da técnica em traços recessivos ligados ao cromossomo X (Simpson, Kuliev \& Rechtsky, 2019). Entretanto, a primeira aplicação clínica do DGPI só foi possível após o desenvolvimento da reação em cadeia da polimerase (PCR), em 1990. Handyside e colaboradores (1990), amplificou sequencias especificas do cromossomo Y, para poder determinar o sexo de embriões de dois casais que apresentavam risco de transmitir adrenoleucodistrofia e deficiência intelectual ligados ao cromossomo X, hoje essa técnica é conhecida como sexagem fetal, muito utilizada para descobrir o sexo do feto, mas também indispensável para o diagnóstico de doenças ligadas ao sexo. Em seguida, Verlinsky e colaboradores (1990) publicaram a respeito de um caso de deficiência de alfa 1 e também o primeiro DGPI para fibrose cística. Grifo e colaboradores relataram a 
primeira gravidez após a biopsia de um embrião submetido a técnica de PCR nos cromossomos X e Y em 1992 (Pizzato et al., 2017).

O estudo das anomalias cromossômicas necessitou esperar mais alguns anos, pois seu desenvolvimento foi a partir da técnica de hibridização in situ de fluorescência (FISH), nos Estados Unidos (Simpson, Kuliev \& Rechtsky, 2019). Griffin e colaboradores em 1991, realizaram um estudo com vários embriões em diversas fases, e observaram a diminuição de abortos após a biopsia através do método de FISH, tanto para anomalias ligadas a cromossomos sexuais, como também moisaicismo. Em 1998, Munné e colaboradores (1998) identificaram translocações cromossômicas com esse método utilizando sondas especificas do ponto de interrupção. Enquanto Verlinsky e colaboradores (2004), aplicaram o FISH da mesma maneira, em corpúsculos polares.

No ano de 1990, Verlinsky organizou um encontro internacional e anual para a partilha sobre as aplicações clínicas do DGPI, que passou a ser chamado da forma apropriada, teste genético pré-implantacional (PGT). No mesmo ano, se iniciou um anual "Grupo de Trabalho Internacional sobre o DGPI", sendo realizado em diversos locais do mundo e muitas vezes acontecendo em conjunto com outros grandes encontros internacionais. Ainda em 1990, ocorreu também a Primeira Conferência Internacional sobre pré-implantação genética, que ocorreu em Chicago com direito a mais uma edição em 1991, encontro que foi organizado por Verlinsky e Kuliev. Tais reuniões se concentraram na investigação inicial do PGT, sendo orientadoras do desenvolvimento de novas tecnologias. Com a comutação de conhecimentos que só os encontros possibilitaram, em pouco tempo o PGT evoluiu, sendo um importante componente do diagnóstico pré-natal, tendo suas devidas indicações distintas, preparando assim o espaço para um progresso rápido que seguiu (Simpson, Kuliev \& Rechtsky, 2019).

Em 2003, foi composta nos Estados Unidos a Preimplantation Genetic Diagnosis International Society (PGDIS), que foi um desdobramento direto do trabalho internacional anual em DGPI. A primeira reunião após a incorporação ocorreu em Londres no ano de 2005. Deste ano em diante, as reuniões ocorrem anualmente e com cedes diferentes, até os dias atuais. Os membros elegeram como primeiro presidente fundador do PGDIS, Yuri Verlinsky. Já na Europa, o workshop de DGPI e comunicação formal são organizações pela sociedade europeia de reprodução humana e embriologia (ESHRE). As atividades de DGPI tem a "proteção" do ESHRE Special Interest Group (SIG) em genética, e, em 1997, formou uma união ESHRE PGD, na qual coletam resultados clínicos anualmente dispondo-os no site da ESHRE e publicações de revisões. Os líderes fundadores dessa união foram Karen Sermon, Joep Geraedts e Joycer Harper (Simpson, Kuliev \& Rechtsky, 2019).

No ano de 2005, a Sociedade Americana de Medicina Reprodutiva (ASRM) formou seu próprio SIG no DGPI, onde a participação estava aberta para todos os membros. Passaram pela presidência, referências como Yury Verlinsky, Jacquas Cohen, Santiago Munné e outros grandes pesquisadores. As reuniões do ASRM PGD SIG que ocorrem anualmente fornecem instruções para atividades de DGPI, incluído assim cursos de pós graduação, revisão de resumos, outros cursos educacionais e eventos científicos até hoje (Simpson, Kuliev \& Rechtsky, 2019).

Neste sentido, após todo o histórico relatado do DGPI, é possível observar que com essa técnica é possível identificar alterações cromossômicas como aneuploidias, definidas como alterações numéricas dos cromossomos, como por exemplo a trissomia do 21, que resulta na síndrome de Down. Também é possível identificar duplicação, quando um fragmento do cromossomo é duplicado, causando a repetição dos genes. Além disso, translocações também são avaliadas, elas ocorrem quando dois ou mais cromossomos não homólogos sofrem quebras, dessa forma, um dos segmentos se liga a parte quebrada do outro. Um exemplo desse fato é o que ocorre no cromossomo Filadélfia, uma translocação entre os cromossomos 9 e 22 . As inversões também são eventos avaliados no DGPI, elas são caracterizadas por duas quebras em um cromossomo unifilamentoso, durante a interfase do ciclo celular, seguidas pela união em posição invertida do fragmento cromossômico intercalado ao restante do cromossomo. Além disso, a deleção é quando acontece a perda total ou parcial de um pedaço do cromossomo, fato também observado pelo DGPI. Além das aneuploidias, doenças monogênicas podem também podem ser 
diagnosticadas através DGPI. As doenças monogênicas são caracterizadas por alteração na sequência codificante do gene, comprometendo a sua função de forma parcial ou total, um exemplo é a anemia falciforme. As mutações que abrangem genes únicos seguem um padrão de herança que pode ser de três tipos: dominante autossômico, recessivo autossômico ou ligado ao X, como descrito por Handyside et al (1990) no caso da deficiência intelectual ligado ao cromossomo X (Pompeu \& Verzeletti, 2015, Harper et al., 2012).

\subsection{Técnicas adotadas para DGPI}

\subsubsection{PCR - Reação em cadeia da polimerase}

A reação em cadeia da polimerase (PCR) é a técnica de biologia molecular mais amplamente utilizada. A técnica consiste na amplificação de uma região específica de DNA, marcada por moléculas iniciadoras de sequência específica e conhecida (primers), que são complementares à fita molde de DNA e irão sinalizar para que a enzima DNA polimerase atue incorporando nucleotídeos que estão livres na reação, gerando milhões de cópias do fragmento que contém o gene de interesse por reação e amplificando de forma exponencial o material genético, de forma que seja possível detectá-lo (Christoff, 2017). O maior desafio do DGPI é a escassez de material genético para realizar a análise, uma vez que na maioria das vezes a biópsia é de apenas uma célula e por este motivo, a amplificação do DNA é parte essencial e necessária para utilizar a técnica de PCR. Apesar dos avanços nas técnicas, um pequeno risco de erro diagnóstico atrelado a este fato ainda existe (Moutou, Gardes \& Viville, 2002).

As principais limitações de realizar a PCR em uma única célula são a possibilidade de contaminação da amostra (como o material é escasso, e não é possível refazer sua coleta, nenhuma quantidade pode ser desperdiçada), a falha completa da PCR e a ocorrência do fenômeno "allelic drop-out" (Dreesen et al., 2013). Este fenômeno consiste na possível falha na amplificação de apenas um dos dois alelos em certo loci, fazendo com que apenas um alelo seja amplificado corretamente. Isso pode ocorrer tanto por falhas analíticas, quanto pela presença de SNVs - single nucleotide variant (Shestak et al., 2021). É importante minimizar sua ocorrência pois impacta a genotipagem de diversas patologias recessivas e dominantes, como fibrose cística, hiperplasia adrenal congênita, hemocromatose hereditária, entre outras patologias, e no contexto do DPGI pode afetar gravemente a qualidade de vida do indivíduo a ser gerado (Blais et al., 2015).

Existem diversas variações de PCR, porém o Nested PCR, Multiplex PCR e RT-PCR (do inglês, real-time PCR) são amplamente utilizadas para o DGPI. O Nested PCR é uma variação da PCR composto por um primeiro round de amplificação utilizando um conjunto externo de iniciadores, seguido de um segundo round, executado com uma quantidade de produto da amplificação do primeiro round (amplicom) e com um par de iniciadores que possui uma sequência de nucleotídeos localizada internamente em relação aos iniciadores utilizados no primeiro round. $\mathrm{O}$ uso de dois conjuntos diferentes de iniciadores para $\mathrm{o}$ mesmo fragmento de DNA a ser amplificado aumenta muito a especificidade do ensaio (Sermon, 2002). O advento deste método se fez muito útil na realização do DPGI, uma vez que na maioria das vezes a biópsia provém de uma única célula, o que resulta em uma quantidade muito pequena de material genético disponível para ser analisado. Como a amplificação é realizada duas vezes, o limiar de detecção utilizando o Nested PCR é menor, o que aumenta o poder de detecção. Apesar disso, a necessidade de se realizar duas rodadas aumenta também a chance de contaminação da amostra e aumenta o tempo do procedimento (Foo et al., 2020; Sermon, 2002).

A multiplex PCR é uma variação da técnica de PCR muito útil no DPGI, pois através dela é possível analisar duas ou mais sequências de DNA simultaneamente, utilizando pares de iniciadores para diferentes genes na mesma reação. Através desta técnica, é possível também minimizar o fenômeno "allelic dropout", este que pode levar a não detecção de um alelo mutante em uma célula heterozigótica e é o fenômeno mais comum associado às técnicas de PCR. Para isto, junto com o gene 
de interesse são amplificados marcadores polimórficos associados, podendo diminuir pela metade o erro diagnóstico pelo fenômeno (Rechitsky, 1998).

A técnica RT-PCR, ou PCR em "tempo real", também chamada de PCR quantitativo (qPCR), consiste na detecção de produtos da PCR a medida em que se acumulam durante a reação. Para isso, são utilizados um conjunto de iniciadores específicos e sondas com marcação fluorescente, que serão detectadas pelo equipamento a medida em que são incorporadas a sequência alvo durante a fase de anelamento, ou durante a fase de extensão. Ao utilizar sondas com marcadores fluorescentes diferentes é possível a análise de mais de um gene ao mesmo tempo (RT-PCR multiplex) (Mocellin et al., 2003; Peters, 2004). O uso desta técnica para o DGPI é muito vantajoso, pois a detecção do produto ocorre durante a reação e é realizada por um computador, portanto não há necessidade de processamento pós-PCR (eletroforese em gel de agarose ou poliacrilamida), resultando em menor risco de contaminação, maior precisão de resultados e redução significativa no tempo do procedimento que pode ser realizado em até 4h após a biópsia, o que é primordial para implantação de embriões frescos. Contudo, qualquer produto que contenha fita dupla (incluído iniciadores) serão detectados, podendo ocasionar falsos positivos decorrentes da formação de produtos inespecíficos. Para minimizar esta ocorrência, é necessário utilizar sondas especificas, que possuem custo elevado, aumentando assim os custos do teste (Mocellin et al., 2003; Peters, 2004; Treff et al., 2012).

\subsubsection{FISH - Hibridização in situ por flourescência}

A FISH é um método utilizado para localizar a presença ou ausência de determinada sequência de DNA, através da hibridação de sondas fluorescentes que possuem alto grau de complementariedade com uma sequência específica. Uma vez que o fluoróforo é acoplado à sequência, esta pode ser identificada através da análise em microscópio fluorescente, ou pode-se detectar a sua ausência (Asif et al., 2018, Harper \& Sengupta, 2011).

A vantagem da FISH em relação a outros métodos é que ela pode ser aplicada nas células em intérfase, portanto, não é necessário cultivá-las até que atinjam a metáfase. O método FISH baseia-se nos seguintes passos: fixação das células da biópsia em uma lâmina, desidratação com álcool para limpar a cromatina fixada do citosol e de artefatos residuais, aplicação das sondas na cromatina fixada, hibridação das sondas, lavagem e aplicação de solução fixadora dos fluoróforo. Todas as etapas após a hibridação devem ser feitas em local com pouca luz para preservação dos fluoróforo (Beyazürek \& Kahraman, 2012).

O número de cromossomos que podem ser investigados simultaneamente no método FISH é limitado pelo número de filtros aplicados ao microscópio, pelo número de fluoróforo disponíveis (apenas 5 tonalidades estão disponíveis nos kits comerciais) e pelo número de células da amostra (normalmente 1 célula). Como apenas 5 fluorocromos têm a definição necessária para serem detectados no espectro ótico, poderão ser analisados no máximo 5 cromossomos na mesma rodada. Para analisar um número maior que 5, o procedimento deve ser feito em duas rodadas e recomenda-se biópsia de duas células, permitindo análise de 16 a 20 cromossomos por embrião. Realizar três rodadas desta técnica gera perda significativa de material da amostra e erros de detecção, por isso não é recomendado (Montazeri et al., 2018).

Atualmente, utiliza-se sondas relativas aos cromossomos X, Y, 13, 14, 15, 16, 17, 18, 21 e 22, na busca por aneuploidias através da FISH, pois anormalidade nestes cromossomos são responsáveis por mais de $50 \%$ dos casos de aborto relacionados a aneuploidias (Beyazyürek \& Kaharaman, 2012).

\subsection{3 aCGH - Hibridização genômica comparativa por array}

A técnica consiste em uma hibridação genômica comparativa, na qual tanto o material genético do paciente quanto o material genético controle (conhecido) são identificados com sondas fluorescentes de cores diferentes e irão competir pela hibridação em sondas previamente fixadas e organizadas a uma lâmina (plataforma). Em seguida, a plataforma é colocada em 
um scanner e a imagem gerada é analisada por um software que identificará deleções e duplicações pela diferença na intensidade da fluorescência (Freitas et al., 2018).

As sondas do controle podem ser constituídas de material genético artificial clonado de bactérias ou por oligonucleotídeos que serão alvos de hibridação. A alteração no número de cópias será interpretada através da intensidade de cor. Quando não há intensidade, o resultado é normal, produção de sinal verde indica ganho relativo de material genético (duplicações), e produção de sinal vermelho indica perda relativa de material (deleções) (Stosic, Levy \& Wapner, 2017).

A maioria das plataformas disponíveis não consegue detectar rearranjos balanceados (quando não há alteração no número de cópias da sequência de DNA). Além disso, níveis baixos de mosaicismo podem não ser detectados. A sensibilidade para detecção do mosaicismo irá depender da plataforma, tipo de amostra, número de cópias, qualidade do material genético, qualidade dos dados e do tamanho do desbalanço. As CNVs (variações no número de cópias) que não estiverem representadas na plataforma utilizada não serão detectadas (South et al., 2013).

Com essa técnica, há a possibilidade de personalizar a plataforma para assim concentrar as sondas em regiões de interesse, sendo assim possível realizar a interpretação dos dados de forma mais simples e objetiva comparada com outros testes (South et al., 2013).

\subsubsection{SNP - Polimorfismo de único nucleotídeo}

Os SNPs (polimorfismos de único nucleotídeo) são o tipo de variação genética mais presente no genoma humano e estão amplamente distribuídos em quase todos os loci gênicos. Essas pequenas variações na sequência de DNA são as grandes responsáveis pela variabilidade genética de populações, pela expressão de características fenotípicas e pelo desenvolvimento de muitas patologias (Govindarajan et al., 2012).

Além disso, os SNPs podem ser decorrentes de trocas entre duas bases purínicas (A/G) ou entre duas bases pirimidínicas $(C / T)$, denominadas transições, ou ainda de trocas entre bases purínicas e pirimidínicas (C/G, G/C, T/A, A/T), denominadas transversões.

Os SNPs podem estar presentes em regiões codificadoras (SNPs exônicos ou codificantes) e não codificadoras (SNPs intrônicos, não codificantes, reguladores ou promotores). Quando estão presentes em regiões codificadoras, o impacto da troca nucleotídica irá depender se a substituição afetará a tradução do aminoácido produzido por aquele gene, de forma que quando há alterações ou ausência da proteína traduzida, a mutação é denominada não sinônima e quando a troca não gera alterações na proteína, a mutação é chamada sinônima. Um SPN promotor, que fica localizado em regiões promotoras do genoma, pode alterar a atividade e expressão do gene (Turchetto-Zolet et al., 2017).

A técnica de análise de SNPs por microarray consiste em amplificação do material genético da amostra (que no caso do DGPI é escasso, por se tratar na maioria das vezes de biópsia de única célula), corte do material em fragmentos de tamanhos determinados, adição de marcadores fluorescentes, hibridização dos fragmentos às sondas selecionadas e presas a um chip, lavagem do material excedente e análise dos dados (Govindarajan et al., 2012).

Após passar por processo de amplificação, as moléculas da amostra de DNA de sequência desconhecida são cortadas em fragmentos através de enzimas de restrição e marcadores fluorescentes são adicionados. Em seguida, o material é colocado em uma lâmina (chip), organizado em linhas e colunas de forma que é possível localizar onde cada fragmento foi colocado. Neste chip, estão fixas dezenas de sondas que são complementares a SNPs alvos, associados a doenças. Essas sondas são selecionadas através de bancos de dados que contém milhares de SNPs conhecidos e são confeccionadas especificamente para as mutações de interesse. Os fragmentos do DNA que são complementares às sondas presas na lâmina irão hibridizar-se a elas, enquanto os que não forem hibridizados serão lavados. Um feixe de laser excita os marcadores fluorescentes e a fluorescência 
emitida é gravada pelo equipamento, tornando possível identificar quais SNPs estão presentes na amostra (Sobrino \& Carracedo, 2005).

Contudo, para ocorrer os ensaios são necessários equipamentos de alto custo, tornando assim o teste mais caro para ser realizado além de ser demorado, pois é composto por procedimentos de alta complexidade (Chen et al., 2017; Handyside, 2011).

\subsubsection{NGS - Sequenciamento de nova geração}

Atualmente, diversas metodologias de sequenciamento de nova geração (NGS) estão disponíveis, porém as mais amplamente utilizadas no Brasil são o sequenciamento Illumina e o sequenciamento Ion Torrent. As técnicas de NGS tem por objetivo determinar a ordem em que os nucleotídeos estão dispostos a molécula de DNA, possibilitando a identificação de mutações genéticas ou de genes causadores de doenças. Elas apresentam conceitos semelhantes, que incluem a geração de uma biblioteca, a amplificação do material genético, o sequenciamento e a análise dos dados. Porém, os processos de amplificação e sequenciamento, apesar de apresentarem mesma finalidade, são diferentes na tecnologia Illumina e Ion Torrent (Christoff, 2017).

Nesta técnica, a geração de biblioteca é um processo de fragmentação física ou enzimática do DNA que foi extraído da amostra, para que sejam formados fragmentos de tamanho compatível com a capacidade de leitura do equipamento, além de formar extremidades livres onde serão hibridizados adaptadores (primers), que são fragmentos de DNA com sequência conhecida (Yohe \& Thaygarajan, 2017). Esses adaptadores podem ainda conter marcadores, que permitem identificar a amostra, possibilitando a análise de várias amostras simultaneamente e diminuindo consideravelmente o custo do procedimento (Simpson, Rechitsky \& Kuliev, 2013).

Os fragmentos gerados pela construção da biblioteca são amplificados a fim de se obter material em quantidade suficiente para o equipamento detectar. A metodologia Illumina é baseada na amplificação em ponte. O DNA que foi fragmentado será hibridizado a primers que estão fixos em uma lâmina (flow cell) e são complementares aos adaptadores adicionados na etapa anterior. A cada ciclo de extensão da PCR, os fragmentos que estão fixos na lâmina por uma extremidade irão hibridizar a outra extremidade, que também possui um primer fixo na lâmina, formando estruturas semelhantes a pontes. Esse fragmento será duplicado através da ação da DNA polimerase, que adicionará nucleotídeos que estão livres na reação, formando uma fita dupla de DNA, que será desnaturada de seu par complementar resultando em fragmentos idênticos ligados à lâmina, cada um com uma extremidade fixada nela e com uma extremidade livre, que em um próximo ciclo irá se ligar a um novo primer, repetindo o processo até se obter a formação de um cluster (um grande número de cópias de um mesmo fragmento) (Christoff, 2017; Goodwin, Mcpherson \& Mccombie, 2016).

A metodologia Ion Torrent utiliza PCR em emulsão para amplificação, que irá ocorrer dentro de uma micela que contém os mesmos materiais que estariam na lâmina do ilumina (os primers complementares de cada extremidade, DNA polimerase, oligonucleotídeos livres) e pequenas esferas (beads) com primers fixados nelas. As cópias geradas daquele fragmento em cada ciclo de extensão vão se prendendo à esfera, povoando sua superfície. Cada esfera é colocada em um chip que contém milhares de micro poços, que comportam apenas uma esfera, para que o sequenciamento seja realizado (Christoff, 2017).

Para determinar o sequenciamento utilizando a metodologia Illumina é realizado um processo no qual serão acrescentados nucleotídeos complementares àquela fita, que estão marcados com fluoróforos de cores diferentes. A enzima DNA polimerase adiciona apenas um nucleotídeo por vez pois esses nucleotídeos são bloqueados e sempre que um é acrescentado, a DNA polimerase para, os nucleotídeos remanescentes são lavados, e um feixe de laser excita o fluoróforo gerando um sinal fluorescente que é detectado e gravado pela máquina, tornando possível identificar exatamente qual 
nucleotídeo foi incorporado. Ao ser incorporado, o bloqueio e a marcação do nucleotídeo são eliminados através de clivagem e um novo ciclo se inicia, onde a DNA polimerase irá incorporar um novo nucleotídeo complementar à sequência, repetindo o processo até o final do sequenciamento (Chaitankar et al., 2016).

$\mathrm{Na}$ metodologia Ion Torrent, apenas um tipo de nucleotídeo é disponibilizado para ser incorporado em cada ciclo do sequenciamento. Cada tipo (G, C, A ou T) é disponibilizado por vez, até que se encontre o que for complementar à fita do fragmento, que está preso à esfera. Quando o nucleotídeo correspondente é incorporado pela DNA polimerase, há a liberação de um átomo de hidrogênio (íon $H^{+}$), que gera uma minúscula alteração no pH que é detectada e gravada pelo equipamento, indicando que aquele nucleotídeo disponível foi incorporado. Quando não se trata do nucleotídeo correspondente, não ocorrerá incorporação e nenhum sinal é gerado. Quando mais de um nucleotídeo são incorporados, a máquina detecta a alteração no pH proporcionalmente, mas regiões repetitivas com mais de 6-8 nucleotídeos iguais não podem ser determinados com sucesso (Yohe \& Thyagarajan, 2017; Christoff, 2017).

Após o sequenciamento, os dados armazenados pelos equipamentos são separados de acordo com a origem da biblioteca da amostra e convertidos em formato compatível com a maioria dos softwares disponíveis. Os dados referentes aos adaptadores adicionados na formação da biblioteca são retirados e são analisados apenas os referentes a sequência de interesse, que são comparados com genomas de referência, disponíveis nos bancos de dados nos softwares. Devido à complexidade dos processos de análises de dados, é recomendado que um profissional especializado em bioinformática realize estes processos (Yohe \& Thyagarajan, 2017; Chaitankar et al., 2016).

Após apresentar as principais técnicas utilizadas para o DGPI, foi realizado a comparação entre os pontos positivos e negativos de cada ensaio (Quadro 1). 
Quadro 1. Pontos positivos e negativos dos testes genéticos aplicados ao DGPI.

\begin{tabular}{|c|c|c|c|}
\hline TESTE & Pontos positivos & Pontos negativos & FONTE \\
\hline Nested PCR & $\begin{array}{l}\text { Maior especificidade para o ensaio; } \\
\text { Necessidade de uma quantidade menor } \\
\text { de material genético. }\end{array}$ & $\begin{array}{l}\text { Maior chance de contaminação; } \\
\text { Procedimento demorado. }\end{array}$ & $\begin{array}{l}\text { Foo et al., 2020; } \\
\text { Sermon, } 2002 .\end{array}$ \\
\hline $\begin{array}{l}\text { Multiplex } \\
\text { PCR }\end{array}$ & $\begin{array}{l}\text { Analise de duas ou mais sequencias ao } \\
\text { mesmo tempo. } \\
\text { Redução de custo e otimização de } \\
\text { tempo; } \\
\text { Minimiza o fenômeno "allele dropout". }\end{array}$ & Maior chance de contaminação. & Rechitsky, 1998 \\
\hline qPCR & $\begin{array}{l}\text { Menor risco de contaminação; } \\
\text { Maior precisão nos resultados; } \\
\text { Redução significativa de tempo; } \\
\begin{array}{l}\text { Analise de mais de um gene } \\
\text { simultaneamente. }\end{array}\end{array}$ & $\begin{array}{l}\text { Aumento de chances de falso positivo; } \\
\text { Custo elevado. }\end{array}$ & $\begin{array}{c}\text { Mocellin et al., } \\
\text { 2003; } \\
\text { Peters, 2004; } \\
\text { Treff } \text { et al., 2012. }\end{array}$ \\
\hline FISH & $\begin{array}{l}\text { Técnica eficiente, de baixo custo, baixa } \\
\text { complexidade e relativamente rápida. }\end{array}$ & $\begin{array}{l}\text { Não é eficiente na detecção de todas as } \\
\text { trissomias; } \\
\text { Limita a quantidade de cromossomos } \\
\text { investigados simultaneamente; } \\
\text { Necessário um controle rigoroso de } \\
\text { qualidade. }\end{array}$ & $\begin{array}{c}\text { Montazeri et al., } \\
\text { 2018; } \\
\text { Beyazyürek \& } \\
\text { Kahraman, 2012. }\end{array}$ \\
\hline aCGH & $\begin{array}{l}\text { Plataforma personalizável; } \\
\text { Interpretação de dados mais simples e } \\
\text { objetiva; } \\
\text { Resultados interfaciados com bancos de } \\
\text { dados. }\end{array}$ & $\begin{array}{l}\text { Grande número das plataformas disponíveis } \\
\text { não consegue detectar rearranjos balanceados; } \\
\text { Sensibilidade baixa para mosaicismo; } \\
\text { As CNVs que não estiverem representadas na } \\
\text { plataforma utilizada não serão detectadas. }\end{array}$ & South et al., 2013. \\
\hline SNP's & $\begin{array}{l}\text { Analise de centenas de milhares de loci } \\
\text { em um único ensaio; } \\
\text { Resultados em alta resolução; } \\
\text { Minimiza a ocorrência do fenômeno } \\
\text { "allele dropout". }\end{array}$ & $\begin{array}{l}\text { Alto custo; } \\
\text { Demorado; } \\
\text { Alta complexidade. }\end{array}$ & $\begin{array}{l}\text { Chen et al., 2017; } \\
\text { Handyside, } 2011 .\end{array}$ \\
\hline $\begin{array}{l}\text { NGS Ion } \\
\text { Torrent }\end{array}$ & $\begin{array}{l}\text { Menor tempo de corrida; } \\
\text { Grande diversidade de chips. }\end{array}$ & $\begin{array}{l}\text { Baixa sensibilidade para regiões repetidas } \\
\text { (com mais de 6-8 nucleotídeos) } \\
\text { Necessário profissional especializado em } \\
\text { bioinformática; } \\
\text { Alto custo. }\end{array}$ & $\begin{array}{l}\text { Christoff, 2017; } \\
\text { Goodwin, } \\
\text { Mcpherson \& } \\
\text { Mccombie, 2016; } \\
\text { Yohe \& } \\
\text { Thyagrajan, 2017. }\end{array}$ \\
\hline $\begin{array}{l}\text { NGS } \\
\text { Illumina }\end{array}$ & $\begin{array}{l}\text { Maior variedade de equipamentos; } \\
\text { Alta confiança nos dados. }\end{array}$ & $\begin{array}{l}\text { Dificuldade em mapear corretamente regiões } \\
\text { homólogas ou regiões ricas em GC, podendo } \\
\text { levar a falsos positivos ou negativos; } \\
\text { Necessário profissional especializado em } \\
\text { bioinformática; } \\
\text { Alto custo. }\end{array}$ & $\begin{array}{l}\text { Christoff, 2017; } \\
\text { Goodwin, } \\
\text { Mcpherson \& } \\
\text { Mccombie, 2016; } \\
\text { Yohe \& } \\
\text { Thyagarajan, } \\
2017 .\end{array}$ \\
\hline
\end{tabular}

Fonte: Autores.

No Quadro 1 é possível relacionar de forma simplificada os pontos positivos e negativos dos ensaios, facilitando assim o entendimento.

\section{3 Ética e testes pré-implantacionais}

$\mathrm{O}$ avanço extraordinário da medicina e da área de biotecnologia, gerou uma capacidade muito maior de intervir na vida humana, em seu início e fim, e de curar enfermidades. Junto com os avanços, vieram os dilemas éticos acerca da interferência humana nos processos naturais da vida. As técnicas de reprodução assistida permitiram que casais com problemas de fertilidade ou idade avançada, até mesmo casais homoafetivos ou pessoas solteiras realizassem o sonho de se reproduzir (Guerra \& Cardin, 2019; Pizzato et al., 2017).

Com o desenvolvimento dos testes genéticos é possível identificar, além de características fenotípicas, possíveis doenças de ordem genética, antes da implantação do embrião, dando aos pais a possibilidade de escolher se querem conviver com uma possível alteração genética, ou se o embrião será descartado. Esse poder decisório se torna alvo de grande dilema 
ético, pois apesar de ainda não se tratar de um indivíduo, o embrião possui todas as potencialidades para se tornar um, portanto não pode ser tratado como um simples objeto sujeito ao descarte (Marambio \& Alcántara, 2018).

O emprego das técnicas de reprodução assistida e do diagnóstico genético pré-implantacional também implicam no desenvolvimento de vários embriões, que mais tarde terão que ser selecionados pelos pais para apenas um (ou até 4) a serem implantados, colocando-os de frente com o dilema de grande responsabilidade em decidir quais serão escolhidos e qual será o destino dos excedentes: descarte, doação para fins de pesquisa ou para outros casais, ou congelamento (Melo-Marín, 2019).

No Brasil, em 2005, frente ao grande avanço biotecnológico, foi criada a Lei de Biossegurança 11.105/2005 que estabelece normas de segurança e mecanismos de fiscalização sobre todas as pesquisas que envolvam material biológico e organismos geneticamente modificados, na busca por um controle eficiente do emprego das biotecnologias, porém, esta lei não é específica quanto às práticas em reprodução assistida (Vettorato, Müller \& Silva, 2019).

Em 2017, o Conselho Federal de Medicina criou a Resolução nº 2.168/2017, que dispõe de normas éticas e administrativas referentes às práticas em reprodução assistida. Segundo a Resolução n².168/2017, as normas são baseadas em princípios éticos e são dispositivos deontológicos (ou seja, norteadores) para a prática médica.

O fato da Resolução n².168/2017 não se tratar de lei específica, mas sim de normas de conduta ética voltada para os médicos que realizam a reprodução assistida, junto com o fato de não estar disposto no Código Penal/1940 (vigente) dispositivo que tipifique os excessos provenientes do uso das técnicas em reprodução assistida, tornam evidente que os dispositivos existentes ainda não resguardam de forma plena e efetiva o embrião humano, que se apresenta vulnerável frente à legislação brasileira (Moreira et al., 2017).

Mesmo na presença destes dispositivos norteadores, o limite de até onde a ciência pode ir está enraizado nas crenças populares e heranças culturais, e depende daquilo que a sociedade qualifica como aceitável (Vettorato, Müller \& Silva, 2019).

O emprego de técnicas que visam a melhora na vida do ser humano que está por nascer é benéfico para a sociedade, porém, se for disponibilizado o uso indiscriminado das técnicas reprodutivas, irá estimular algo que foi combatido durante a Segunda Guerra Mundial: a eugenia (Moreira et al., 2017). A escolha genética dos pais não pode contemplar o poder de determinar as principais características que o futuro filho apresentará, correspondendo com suas expectativas quanto à estética do bebê, e quanto a garantia de não convivência com qualquer tipo de enfermidade ou deficiência (Marambio \& Alcántra, 2018), o que aumenta ainda mais o estigma da discriminação contra pessoas com deficiências ou outras características qualificadas como indesejáveis pela sociedade (Melo-Martín, 2019).

Na Resolução n².168/2017 do Conselho Federal de Medicina, artigo I, alínea 5, está disposto que as técnicas de reprodução assistida não poderão ser empregadas para seleção de sexo (presença ou ausência do cromossomo Y), tampouco para seleção de qualquer característica biológica que não tenha por finalidade evitar uma anomalia genética. Já o artigo VI, alínea 1, permite o descarte (ou doação para fins de pesquisa) do embrião que apresentar "alterações genéticas causadoras de anomalias", após passar por diagnóstico genético pré-implantacional.

Nota-se que não foi caracterizada qual anomalia poderia ser um critério para seleção ou descarte do embrião, deixando uma lacuna que poderia ser explorada para a não convivência com qualquer tipo de enfermidade ou defeito, inclusive aqueles que não afetariam de forma significativa a qualidade de vida do indivíduo a ser gerado (Moreira et al., 2017). Em países como Dinamarca, França, Alemanha, Holanda, Noruega, Suíça e Reino Unido, o diagnóstico genético préimplantacional só é permitido em situações nas quais existe um significante ou altíssimo risco de conceber uma criança com "séria desordem genética", mas também não é especificado em legislação quais desordens permitiriam a aplicação dos testes (Dondorp \& Wert, 2018).

A seleção de embriões através do diagnóstico genético pré-implantacional pode oferecer benefícios significantes para os futuros pais e sociedade, porém esses possíveis benefícios não são isentos de custos, tanto financeiros, como morais e éticos 
(Melo-Martín, 2019). Não podemos esquecer das atrocidades do aprimoramento genético que buscava a eugenia nazista. O poder decisório entre bem e mal concebido à ciência pode-se tornar um poderoso instrumento de dominação social e política se não for baseado em conceitos elevadíssimos de ética profissional e consciência do desenvolvimento natural da espécie humana (Moreira et al., 2017).

\section{Considerações Finais}

O DGPI foi reportado pela primeira vez na década de 90, e desde então vem sofrendo avanços que acompanham o desenvolvimento das técnicas de biologia molecular e de biópsia de embriões.

Através do DGPI é possível identificar alterações cromossômicas como aneuploidias, translocações e doenças monogênicas no DNA do embrião de casais que procuram as técnicas de reprodução assistida para se reproduzir, com o objetivo de selecionar embriões para implantação com as maiores chances de serem saudáveis. Além disso, também se tornou possível a seleção de embriões com HLA (antígenos leucocitários humanos) compatível com o de um filho já nascido, que apresenta doença congênita ou adquirida na medula óssea, com intuito de se gerar um doador de medula.

É fato que o DGPI confere grande avanço no campo da reprodução assistida e possibilita mulheres com idade avançada ou histórico recorrente de aborto, além de pessoas com anomalias genéticas, terem o DNA de seus embriões analisados antes da transferência embrionária, permitindo a identificação de mutações que poderão afetar a saúde do bebê e garantindo a sua compatibilidade com a vida. Entretanto, as técnicas de DGPI ainda podem apresentar falhas no diagnóstico e seus possíveis benefícios não são isentos de custos, tanto financeiros, como morais e éticos. Dessa forma, seria de extrema importância novas pesquisas, na tentativa de aprimorar as técnicas de DGPI e diminuir seus custos, para que assim, o DGPI venha a ser mais acessível na Reprodução Assistida.

\section{Referências}

Asif, A., Mushtaq, S., Hassan, U., Akhtar, N., Hussain, M., Azam, M. \& Qazi, R. (2018) Fluorescence in Situ Hybridization (FISH) for Differential Diagnosis of Soft Tissue Sarcomas. Asian Pacific journal of cancer prevention, 19(3), 655 - 660.

Beyazyürek, Ç. \& Kahraman, S. (2012) Invasive techniques: Aneuploidy testing by FISH. A practical guide to selecting gametes and embryos. Cap. 17, p. 241-253.

Blais, J., Lavoie, S. B., Giroux, S., Bussières, J., Lindsay, C., Dionne, J., Laroche, M., Giguère, Y. \& Rousseau, F. (2015) Risk of misdiagnosis due to allele dropout and false-positive PCR artifacts in molecular diagnostics. The Journal of Molecular Diagnostics, 17(5), 505-514.

Chaitankar, V., Karakülah, G., Ratnapriya, R., Giuste, F. O., Brooks, M. J. \& Swaroop, A. (2016) Next generation sequencing technology and genomewide data analysis: Perspectives for retinal research. Progress in Retinal and Eye Research Journal, 55, 1-31.

Chen, L., Diao, Z., Xu, Z., Zhou, J., Yan, G. \& Sun, H. (2017) The clinical application of NGS-based SNP haplotyping for PGD of Hb H disease. Systems Biology in Reproductive Medicine, 63(3), 212-217.

Christoff, A. P. (2017) Genômica e sequenciamento de nova geração. Marcadores Moleculares na Era Genômica: Metodologias e Aplicações, Cap. 2, p. 21$50,2017$.

Dondorp, W. \& Wert, G. (2018) Refining the ethics of preimplantation genetic diagnosis: a plea for contextualizated proporcionality. Bioethics, 33(2), 294301.

Dreesen, J., Destouni, A., Kourklaba, G., Degn, B., Mette, W. C., Carvalho, F., Moutou, C., Sengupta, S., Dhanjal, S., Renwick, P., Davies, S., Kanavakis, E., Harton, G. \& Traeger-Synodinos, J. (2013) Evaluation of PCR-based preimplantation genetic diagnosis applied to monogenic diseases: a collaborative ESHRE PGD consortium study. European Journal of Human Genetics, 22(8), 1012-1018.

Ferreira, I. E. R. (2017) O avanço da genética no contexto da reprodução humana: uma revisão de literatura. Revista Interdisciplinar Ciências e Saúde, 4(2), $61-70$.

Foo, P. C., Nakian, A. B. N., Muhamad, N. A., Ahamad, A., Mohaned, M., Yean, C. Y. \& Lim, B. H. (2020) Loop-mediated isothermal amplification (LAMP) reaction as viable PCR substitute for diagnostic applications: a comparative analysis study of LAMP, conventional PCR, nested PCR (nPCR) and real-time PCR (qPCR) based on Entamoeba histolytica DNA derived from faecal sample. BMC Biotechnology, 20(34), 1-15.

Freitas, M., Pinto, J., Ramalho, C. \& Dória, S. (2018) Prenatal diagnosis: the clinical usefulness of array comparative genomic hybridization. Porto Biomedical Journal, 3(2), 1-6. 
Gonçalves, G. P., Neto, J. M. S., Pereira, I. L., Cardozo, M. L., Marinho, M. D., Estrela, M. R. A. \& Arruda, J. T. (2019) Implicações do diagnóstico genético pré-implantação na análise dos erros inatos do metabolismo na prática clínica. RESU - Revista Educação em Saúde, 7(1), 311-316.

Govidarajan, R., Duraiyan, J., Kaliyappan, K. \& Palanisamy, M. (2012) Microarray and its applications. Journal of Pharmacy and BioAllied Sciences, 4(6), $310-312$.

Griffin, D. K., Handyside, A. H., Peneketh, R. J.A., Winston, R. M. L. \& Delhanty, J. D. A. (1991) Fluorescent in- situ hybridization to interphase nuclei of human preimplantation embryos with X and Y chromosome specific probes. Revista Human Reproduction, 6, 101-105.

Grifo, J. A., Tang, Y. X., Cohen, J., Gilberti, F., Sanyal, M. K. \& Rosenwaks, Z. (1992) Pregnancy after embryo biopsy and coamplification of DNA from X and Y chromosomes. The Journal of the American Medical Association, 268, 727-729.

Goodwin, S., Mcpherson, J. D. \& Mccombie, W. R. (2016) Coming of age: ten years of next generation sequencing technologies. Nature Reviews Genetics, $17,333-351$.

Guerra, M. G. R. M. \& Cardin, V. S. G. (2019) Do diagnóstico genético pré-implantacional para a seleção de embriões com fins terapêuticos: uma análise do bebê-medicamento. Revista da Faculdade de Direito da UERJ, (35), 60-77.

Handyside, A. H. (2011) PGD and aneuploidy screening for 24 chromosomes by genome-wide SPN analysis: seeing the wood and the trees. Reproductive BioMedicine Online, 23, 686-691.

Harper, J. C. \& Sengupta, S. B. (2011) Preimplantation genetic diagnosis: State of the ART 2011. Human Genetics Journal, 131, $175-186$.

Harper, J. C., Wilton, L., Traeger-Synodinos, J., Goossens, V., Moutou, C., Sengupta, S. B., Budak, T. P., Renwick, P., Rycke, M., Geraedts, J. P. M. \& Harton, G. (2012) The ESHRE PGD Consortiun: 10 year of data collection. Human Reproductive Updates, 18(3), $234-247$.

Harton, G. L., De Rycke, M., Fiorentino, F., Moutou, C., Sengupta, S., Traeger-Synodinos, J. \& Harper, J. C. (2011) ESHRE PGD consortium best practice guidelines for amplification-based PGD. Human Reproduction, 26(1), 33-40.

Lima, C. V. T. C. \& Silva, H. B. (2017) Resolução n².168 de 21 de setembro de 2017. Diário oficial da União, edição 216 , seção 1 , p. 73.

Marambio, J. T. \& Alcántara, M. J. S. (2018) Ethical problems with the preimplantation genetic diagnosis of human embryos. Acta Biomedica, 24(1), 75-83.

Melo-Martín, I. (2019) The challenge for medical ethicists: weighing pros and cons of advanced reproductive technologies to screen human embryos during IVF. Human Embryos and Preimplantation Genetic Technologies: Ethical, Social and Public Policy Aspects. Capítulo 1, p. 1-10.

Mocellin, S., Rossi, C. R., Pilati, P., Nitti, D. \& Marincola, F. M. (2003) Quantitative real-time PCR: a powerful ally in cancer research. TRENDS in Molecular Medicine, 9(8), 189-195.

Montazeri, F., Foroughmand, A. M., Kalantar, S. M., Aflatoonian, A. \& Khalilli, M. A. (2018) Tips and tricks in Fluorescence In-situ Hybridization (FISH)based Preimplantation Genetic Diagnosis/Screening (PGD/PGS). International Journal of medical Laboratory, 5, 84-98.

Moreira, R. V., Reis, V. M. S., Souza, C. H. M., Cabral, R. B. \& Ribeiro, L. M. T. B. (2017) Reprodução humana assistida: relação entre ciência e sociedade face à bioética. Interdisciplinary Scientific Journal, 5(4), artigo 17.

Moutou, C., Gardes, N. \& Viville, S. (2002) Multiplex PCR combining deltaF508 mutation and intragenic microsatellites of the CFTR gene for preimplantation genetic diagnosis (PGD) of cystic fibrosis. European Journal of Human Genetics, 10, 231-238.

Munnes, S., Fung, J., Cassel, M. J., Marquez, C. \& Weier, H. U. G. (1998) Preimplantation genetic analysis of translocations: case - specific probes for interphase cell analysis. Jornal Hum Genet, 102, 663-674.

Pereira, A. S., Shitsuka, D. M., Parreira, F. J., \& Shitsuka, R. (2018). Metodologia da pesquisa científica. UFSM. https://repositorio.ufsm.r/bitstream/handle/1/15824/Lic_Computacao_Metodologia-Pesquisa-Cientifica. Pdf.

Peters, I. R., Helps, C. R., Hall, E. J. \& Day, M. J. (2004) Real-time RT-PCR: considerations for efficient and sensitive assay design. Journal of Immunological Methods, 286, 203-207.

Pizzato, B. R., Pacheco, C. M. R., Ferreira, L. S. \& Verzeletti, F. C. (2017) Revisão das técnicas de biologia molecular aplicadas no diagnóstico genético préimplantacional e uma reflexão ética. Sociedade Brasileira de Reprodução Humana. Revista Reprodução e Climatério, 32(1), 7-14.

Pompeu, T.N. \& Verzeletti, F.B. (2015) Diagnostico Genético Pré-Implantacional e Sua Aplicação na Reprodução Humana Assistida. Sociedade Brasileira de Reprodução Humana. Revista Reprodução e Climaterio, 30(2), 83-89.

Proetti, S. (2018). As pesquisas qualitativa e quantitativa como métodos de investigação científica: Um estudo comparativo e objetivo. Revista Lumen ISSN: 2447-8717, 2 (4). 10.32459/revistalumen.v2i4.60.

Rechitsky, S., Strom, C., Verlinsky, O., Amet, T., Ivakhnenko, V., Kukharenko, V., Kuliev, A. \& Verlinsky, Y. (1998) Allele dropout in polar bodies and blastomeres. Journal of Assisted Reproduction and Genetics, 15(5), 253-257.

Sermon, K. (2002) Current concepts in preimplantation genetic diagnosis (PGD): a molecular biologist's view. Human Reproduction, 8(1), 11-20.

Shestak, A. G., Bukaeva, A. A., Saber, S. \& Zaklyazminskaya, E. V. (2021) Allelic dropout is a common phenomenon that reduces the disgnostic yield of PCR-based sequencing of targeted gene panels. Frontiers in Genetics, 12, 1-7.

Simpson, J. L., Rechitsky, S. \& Kuliev, A. (2003) Next-generation sequencing for preimplantation genetic diagnosis. Fertility and Sterility Journal, 99(5), 1203-1204. 
Research, Society and Development, v. 10, n. 15, e429101523103, 2021

(CC BY 4.0) | ISSN 2525-3409 | DOI: http://dx.doi.org/10.33448/rsd-v10i15.23103

Simpsion, J.L., Kuliev, A. \& Rechitsky, S. (2019) Oerview of Preimplantation Genetic Diagnosis (PGD): Historical Perpective and Future Direction. Revista Prenatal Diagnosis. Methods in Molecular Biology, 1885, 23-38.

Sobrino, B. \& Carracedo, A. (2005) SNP Typing in forensic genetics. Methods in molecular biology: Forensic DNA typing protocols, 297(8),107-126.

South, S. T., Lee, C., Lamb, A. N., Higgings, A. W. \& Kearney, H. M. (2013) ACMG Standards and Guidelines for constitutional cytogenomic microarray analysis, including postnatal and prenatal applications: revision 2013. Genetics in Medicine, 15(11), 901-909.

Stosic, M., Levy, B., Wapner, R. (2017) The use of chromosomal microarray analysis in prenatal diagnosis. Obstetrics and Gynecology Clinics of North America Journal.

Sullivan-Pyke, C. \& Dokras, A. (2018) Preimplantation genetic screening and preimplantation genetic diagnosis. Revista Obstetrics and Gynecology Clinics of North America, 45(1), 113-125.

Treff, N. R., Tao, X., Ferry, K. M., Su, J., Taylor, D. \& Scott, R. T. (2012) Development and validation of an accurate quantitative real-time polymerase chain reaction-based assay for human blastocyst comprehensive chromosomal aneuploidy screening. Seminal Contribution, 97(4), 819-842.

Turchetto-Zolet, A. C., Turchetto, C., Guzman, F., Silva-Arias, G. A., Sperb-Ludwing, F. \& Veto, N. M. (2017) Polimorfismo de Nucleotídeo Único (SNP): metodologias de identificação, análise e aplicações. Marcadores Moleculares na Era Genômica: Metodologias e Aplicações, Cap. 8, $132-179$.

Verlinsky, Y., Cieslak, J., Ivakhnenko, V., Wolf, G., Kovalinskaya, L., White, M., Lifchez, A., Kaplan, B., Moise, J., Valle, J., Ginberg, N., Strom, C. \& Kuliev, A. (1995) Pregnancies following pré- conception diagnosis of common aneuploidies by fluorescent in- situ hybridization. Revista Molecular Human Reproduction, 1, 265-269.

Verlinsky, Y., Cohen, J., Munne, S., Gianaroli, L., Simpson, J. L., Ferrareti, A. P. \& Kuliev, A. (2004) Over a decade of experience with preimplantation genetic diagnosis: a multicenter report. Fertility and Sterility, 82(2), 292-294.

Verlinsky, Y., Ginsberg, N., Lifchez, A., Valle, J., Moise, J. \& Strom, C.M. (1990) Analysis of the polar body: preconception genetic diagnosis. Revista Human Reproduction, 5, 826-839.

Vettorato, J. G., Müller, N. T. G. \& Silva, D. H. (2019) Bioética: vida humana como objeto de experiência científica. Revista Interdisciplinar de Ciências Aplicadas, 4(7).

Yohe, S. \& Thyagarajan, B. (2017) Review of clinical next-generation sequencing. Archives of Pathology \& Laboratory Medicine, 141, $1544-1557$. 